\title{
Kampo (Traditional Japanese Herbal) Formulae for Treatment of Stomatitis and Oral Mucositis
}

\author{
Masataka Sunagawa ${ }^{D}$, Kojiro Yamaguchi ${ }^{\circledR}$, Mana Tsukada, Nachi Ebihara, Hideshi Ikemoto \\ and Tadashi Hisamitsu *D
}

Department of physiology, School of medicine, Showa University, Tokyo 142-8555, Japan; suna@med.showa-u.ac.jp (M.S.); kampo5260@icloud.com (K.Y.); m-tsukada@med.showa-u.ac.jp (M.T.); BYS00426@nifty.com (N.E.); h_ikemoto@med.showa-u.ac.jp (H.I.)

* Correspondence: tadashi@med.showa-u.ac.jp; Tel.: +81-3-3784-8110

Received: 10 November 2018; Accepted: 29 November 2018; Published: 10 December 2018

\begin{abstract}
Stomatitis is occasionally multiple, recurrent, and refractory. Currently, mucositis induced by chemotherapy and radiation therapy in patients with cancer has become a significant clinical problem. Effective treatments have not been established and the treatment of numerous cases remains a challenge for physicians. Traditional Japanese herbal medicines termed Kampo formulae (i.e., Hangeshashinto, Orengedokuto, Inchinkoto, Orento, Byakkokaninjinto, Juzentaihoto, Hochuekkito, and Shosaikoto) are used for treating various types of stomatitis and mucositis. Its use has been based on the Kampo medical theories-empirical rules established over thousands of years. However, recently, clinical and basic research studies investigating these formulae have been conducted to obtain scientific evidence. Clinical studies investigating efficacies of Shosaikoto and Orento for the treatment of cryptogenic stomatitis and acute aphthous stomatitis and those investigating the effects of Hangeshashinto, Orengedokuto, and Juzentaihoto on chemotherapy- or radiotherapy-induced mucositis have been conducted. The Kampo formulae comprise several crude drugs, whose mechanisms of action are gradually being clarified. Most of these drugs that are used for the treatment of stomatitis possess anti-inflammatory, analgesic, and antioxidative properties. In this review, we introduce the clinical applications and summarize the available evidence on the Kampo formulae for the treatment of stomatitis and oral mucositis.
\end{abstract}

Keywords: kampo formula; traditional Japanese herbal medicine; stomatitis; mucositis; Hangeshashinto

\section{Introduction}

Stomatitis is a sore and often recurrent inflammatory condition of the oral mucosa, characterized by various symptoms such as the presence of vesicles, erosions, aphthae, and ulcerations. Stomatitis is caused by various factors such as viral, fungal, and bacterial infections, allergic reactions, loose-fitting dental prosthetics, and systemic diseases. Occasionally, stomatitis is multiple, recurrent, and refractory. Currently, mucositis induced by chemotherapy and radiation therapy in patients with cancer has become a significant clinical problem [1]. The pain associated with mucositis often affects a patient's functional status and quality of life.

Kampo formula, a traditional Japanese herbal medicine, has its root in ancient Chinese medicine, and the antecedent form of medicine was introduced to Japan between the 5th and 6th century. It was developed into an individual form of medicine adapting the constitutions of the Japanese people. Kampo formulae have been reported to be effective for the treatment of stomatitis and mucositis [2,3]. The objective of this review was to introduce the clinical applications and summarize the available evidence on the Kampo formulae for the treatment of these two conditions. 


\section{Clinical Applications}

We conducted a questionnaire survey regarding the treatment of stomatitis using the Kampo formulae. According to the results, formulae such as Hangeshashinto (HST), Orengedokuto (OGT), Inchinkoto (ICT), Orento (ORT), Byakkokaninjinto (BKN), Juzentaihoto (JTT), Hochuekkito (HET), and Shosaikoto (SST) were used (Figure 1) [4]. The Kampo formulae are generally composed of at least two kinds of crude drugs and these combinations may suppress the development of infections, inflammation, concomitant oxidative stress, and the underlying causes of stomatitis. The chief ingredient and principal effects of each crude drug included in the formulae frequently used for the treatment of stomatitis are shown in Table 1. Many of these agents possess anti-inflammatory and/or analgesic properties. Of note, Astragali Radix, Scutellariae Radix, Phellodendri Cortex, Coptidis Rhizoma, Glycyrrhizae Radix, Bupleuri Radix, Paeoniae Radix, Artemisiae Lanceae Rhizoma, Cimicifugae Rhizoma, Cnidii Rhizoma, Angelicae Radix, and Poria exert anti-inflammatory effects. Moreover, Cinnamomi Cortex, Cimicifugae Rhizoma, Paeoniae Radix, Glycyrrhizae Radix, Cnidii Rhizoma, Angelicae Radix, Zingiberis Rhizoma Processum, and Magnoliae Cortex exert analgesic effects [5]. The occurrence of stomatitis is related to the generation of reactive oxygen species (ROS) [6]. Therefore, anti-oxidants contained in these medicinal herbs may effectively mitigate this damaging effect. Dragland et al. [7] assessed the contribution of culinary and medicinal herbs to the total dietary intake of anti-oxidants (Table 1). Notably, Cinnamomi Cortex, Scutellariae Radix, Cimicifugae Rhizoma, Paeoniae Radix, Aurantii Nobilis Pericarpium, and Glycyrrhizae Radix contain high concentrations of anti-oxidants.

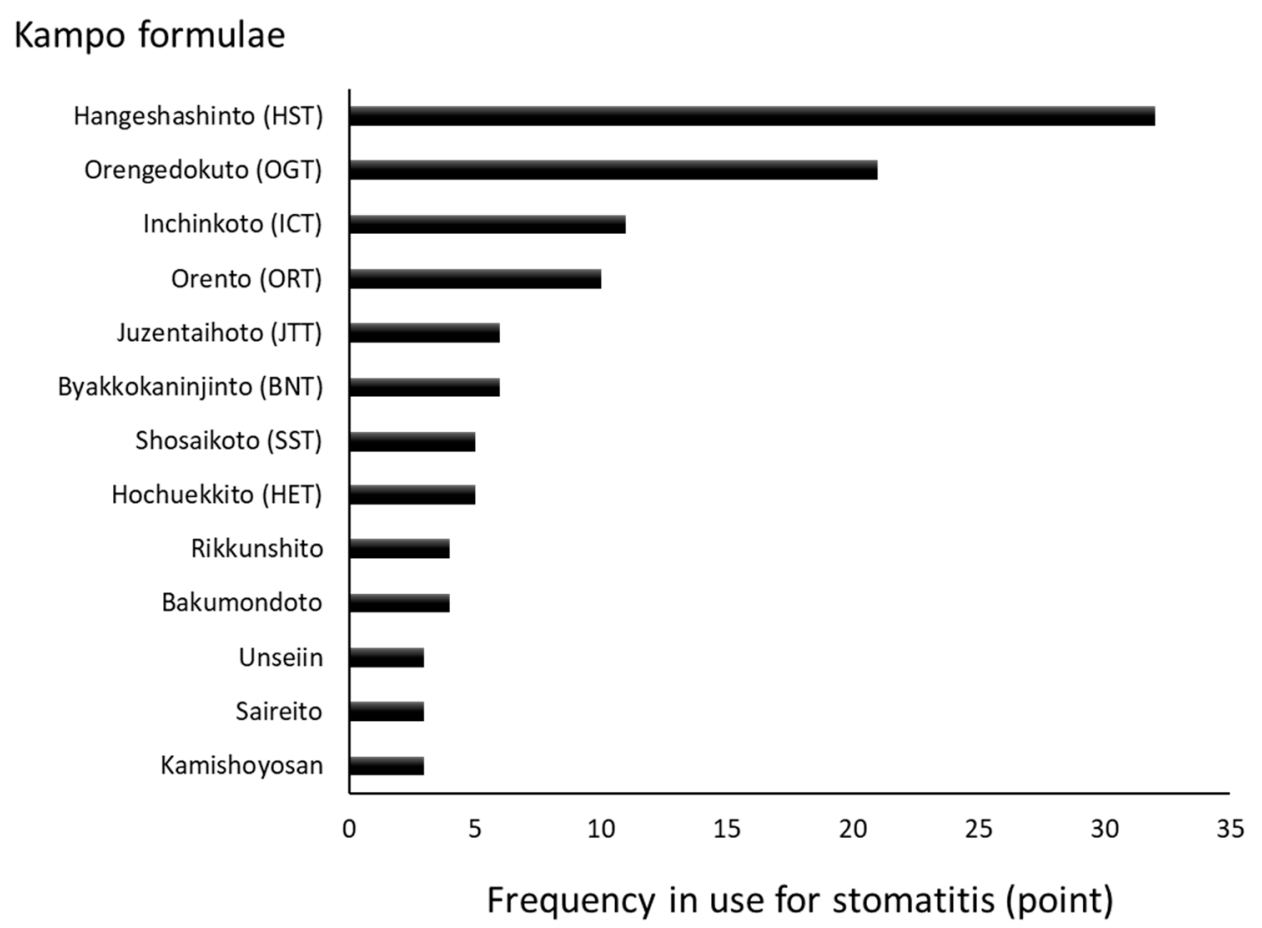

Figure 1. Kampo formulae frequently used for the treatment of stomatitis [4]. The trends in the use of the Kampo formulae at hospitals and faculties of oral surgery of dental/medical universities in Japan were surveyed. A total of 55 hospitals participated in the survey and rated the frequency of Kampo formulae use via a scale from 0 to 3 . This graphic summarizes the results of rating. 
Table 1. The Kampo formulae frequently used for the treatment of stomatitis and their corresponding crude drugs.

\begin{tabular}{|c|c|c|c|c|c|c|c|c|c|c|c|c|c|}
\hline \multicolumn{14}{|c|}{ Kampo Formulae } \\
\hline \multicolumn{2}{|c|}{$\begin{array}{c}\text { Crude Drug/ } \\
\text { Japanese Name }\end{array}$} & $\begin{array}{l}\text { Hangeshashinto } \\
\text { (HST) }\end{array}$ & $\begin{array}{l}\text { Orento } \\
\text { (ORT) }\end{array}$ & $\begin{array}{l}\text { Orengedokuto } \\
\text { (OGT) }\end{array}$ & $\begin{array}{l}\text { Byakkokaninjinto } \\
\text { (BKN) }\end{array}$ & $\begin{array}{l}\text { Shosaikoto } \\
\text { (SST) }\end{array}$ & $\begin{array}{c}\text { Inchinkoto } \\
\text { (ICT) }\end{array}$ & $\begin{array}{l}\text { Heiisan } \\
\text { (HIS) }\end{array}$ & $\begin{array}{l}\text { Juzentaihoto } \\
\text { (JTT) }\end{array}$ & $\begin{array}{c}\text { Hochuekkito } \\
\text { (HET) }\end{array}$ & $\begin{array}{c}\text { Antioxidant } \\
{[7]} \\
(\mathrm{mmol} / 100 \mathrm{~g})\end{array}$ & $\begin{array}{c}\text { Chief } \\
\text { Ingredient }\end{array}$ & Principal Effects \\
\hline $\begin{array}{l}\text { Cinnamomi } \\
\text { Cortex }\end{array}$ & Keihi & & O & & & O & & & ○ & & 120.2 & cinnamaldehyde & $\begin{array}{c}\text { antipyresis, } \\
\text { perspiration, analgesia }\end{array}$ \\
\hline $\begin{array}{l}\text { Scutellariae } \\
\text { Radix }\end{array}$ & Ogon & O & & 0 & & O & & & & & 111.5 & baicalin & $\begin{array}{l}\text { anti-inflammation, } \\
\text { antipyresis, laxative }\end{array}$ \\
\hline $\begin{array}{l}\text { Cimicifugae } \\
\text { Rhizoma }\end{array}$ & Shoma & & & & & & & & & 0 & 64.3 & cimigenol & $\begin{array}{c}\text { anti-inflammation, } \\
\text { antipyresis, analgesia, } \\
\text { antiedema }\end{array}$ \\
\hline $\begin{array}{l}\text { Paeoniae } \\
\text { Radix }\end{array}$ & Shakuyaku & & & & & O & & & 0 & & 55.1 & paeoniflorin & $\begin{array}{l}\text { analgesia, spasmolysis, } \\
\text { anti-inflammation }\end{array}$ \\
\hline $\begin{array}{c}\text { Aurantii } \\
\text { Nobilis } \\
\text { Pericarpium }\end{array}$ & Chinpi & & & & & & & 0 & & 0 & 17.5 & hesperidin & stomachic, antitussive \\
\hline $\begin{array}{l}\text { Glycyrrhizae } \\
\text { Radix }\end{array}$ & Kanzo & 0 & ○ & & 0 & ○ & & o & 0 & 0 & 11.6 & glycyrrhizin & $\begin{array}{l}\text { anti-inflammation, } \\
\text { analgesia, detoxification }\end{array}$ \\
\hline $\begin{array}{l}\text { Zingiberis } \\
\text { Rhizoma }\end{array}$ & Shokyo & & & & & 0 & & ○ & & 0 & 7.5 & gingerol & stomachic, antinausea \\
\hline $\begin{array}{l}\text { Atractylodis } \\
\text { Lanceae } \\
\text { Rhizoma }\end{array}$ & Sojutsu & & & & & & & 0 & 0 & 0 & 7.4 & atractylodin & $\begin{array}{l}\text { anti-inflammation, } \\
\text { stomachic, diuresis }\end{array}$ \\
\hline $\begin{array}{l}\text { Cnidii } \\
\text { Rhizoma }\end{array}$ & Senkyu & & & & & & & & ○ & & 6.7 & cnidilide & $\begin{array}{l}\text { analeptic, nourishing, } \\
\text { anti-inflammation, } \\
\text { analgesia }\end{array}$ \\
\hline $\begin{array}{l}\text { Zizyphi } \\
\text { Fructus }\end{array}$ & Taiso & O & O & & & 0 & & 0 & & 0 & 5.9 & $\begin{array}{c}\text { zizyphus } \\
\text { saponin }\end{array}$ & $\begin{array}{l}\text { analeptic, nourishing, } \\
\text { stomachic }\end{array}$ \\
\hline $\begin{array}{l}\text { Bupleuri } \\
\text { Radix }\end{array}$ & Saiko & & & & & 0 & & & & 0 & 5.7 & saikosaponin & $\begin{array}{l}\text { anti-inflammation, } \\
\text { antipyresis }\end{array}$ \\
\hline $\begin{array}{l}\text { Astragali } \\
\text { Radix }\end{array}$ & Ogi & & & & & & & & 0 & 0 & 4.9 & formononetin & $\begin{array}{c}\text { anti-inflammation, } \\
\text { analeptic, diuresis, } \\
\text { hypotensive }\end{array}$ \\
\hline $\begin{array}{l}\text { Rhemanniae } \\
\text { Radix }\end{array}$ & Jio & & & & & & & & O & & 3.9 & catalpol & nourishing, diuresis \\
\hline $\begin{array}{c}\text { Angelicae } \\
\text { Radix }\end{array}$ & Toki & & & & & & & & 0 & 0 & 3.0 & ligustilide & $\begin{array}{c}\text { analeptic, nourishing, } \\
\text { anti-inflammation, } \\
\text { analgesia } \\
\end{array}$ \\
\hline Hoelen & Bukuryo & & & & & & & & 0 & & 2.8 & eburicoic acid & antiedema, stomachic \\
\hline $\begin{array}{l}\text { Ginseng } \\
\text { Radix }\end{array}$ & Ninjin & ○ & ○ & & ○ & ○ & & & ○ & 0 & 1.5 & ginsenoside & $\begin{array}{l}\text { stomachic, nourishing, } \\
\text { antinausea }\end{array}$ \\
\hline
\end{tabular}


Table 1. Cont.

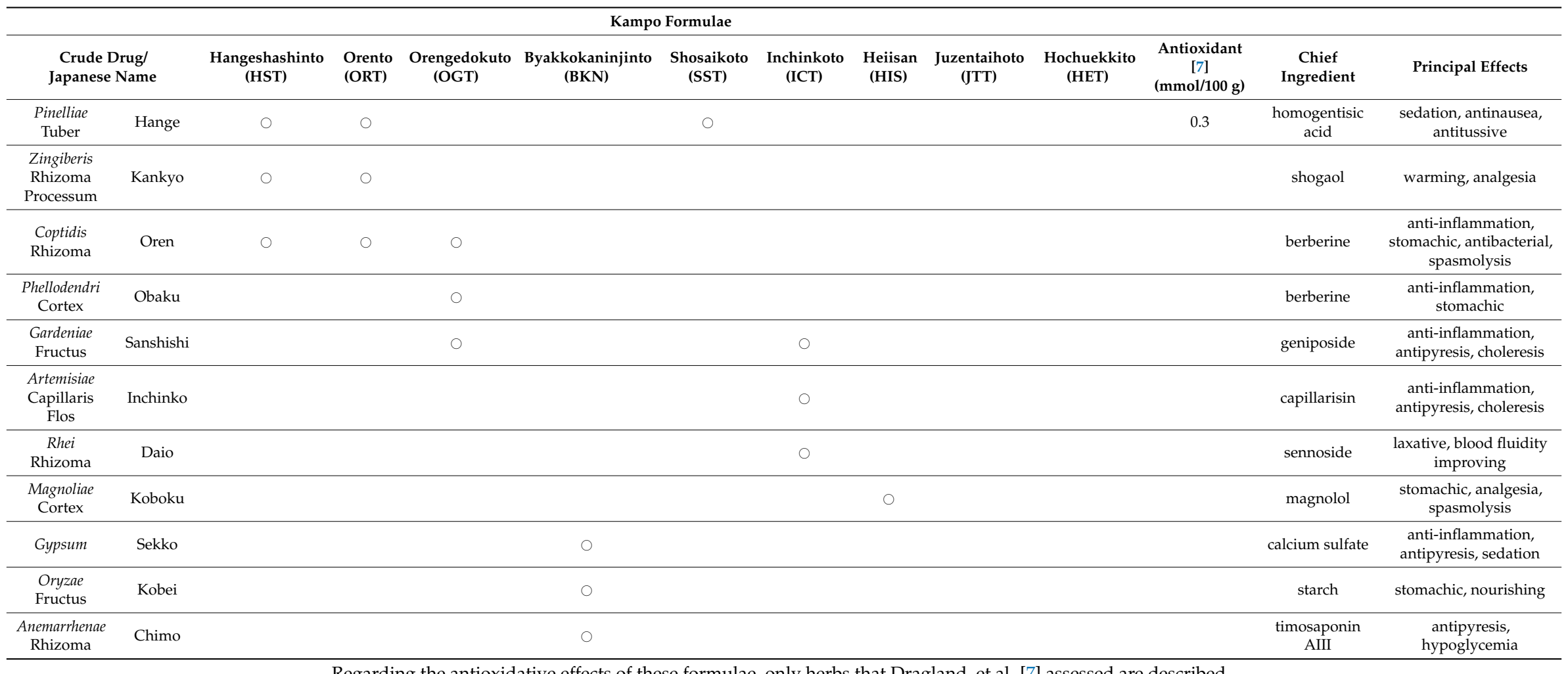

Regarding the antioxidative effects of these formulae, only herbs that Dragland, et al. [7] assessed are described. 
In addition, Cinnamomi Cortex, Scutellariae Radix, Glycyrrhizae Radix, Astragali Radix, Coptidis Rhizoma, and Phellodendri Cortex inhibit several bacterial infections. Moreover, Cinnamomi Cortex, Scutellariae Radix, and Anemarrhenae Rhizome exert antifungal effects. Furthermore, Scutellariae Radix and Glycyrrhizae Radix have been shown to inhibit viral infections [8].

In Kampo medicine, the approach to the treatment of stomatitis differs depending on the nature of the symptoms (i.e., acute or chronic). Furthermore, the most appropriate treatment is determined according to the presence of oral and general symptoms. The effectiveness of each Kampo formula according to the pathognomonic symptoms of patients is shown in Table 2. In the acute type, formulae exerting cooling effects (i.e., HST, ORT, OGT, BNT, SST, and ICT) are used. In the chronic type, formulae such as HIS, JTT, and HET are used [3]. The JTT and HET supply energy in patients with symptoms of tiredness, fatigue, or lowered/suppressed immunity $[9,10]$. The oral cavity is a part of the digestive system; thus, digestive symptoms are important selection criteria for the Kampo formulae. The HST, ORT, OGT, SST, ICT, HIS, JTT, and HET are applied for the treatment of gastrointestinal diseases and symptoms by the national health insurance in Japan.

Table 2. The effectiveness of each Kampo formula according to the pathognomonic symptoms of patients.

\begin{tabular}{ll}
\hline Kampo Formulae & Pathognomonic Symptoms \\
\hline Hangeshashinto (HST) & $\begin{array}{l}\text { multiple stomatitis } \\
\text { irritation, anxiety, insomnia, rush of blood to the head, anorexia, diarrhea, } \\
\text { epigastric discomfort and resistance }\end{array}$ \\
\hline Orento (ORT) & $\begin{array}{l}\text { multiple stomatitis } \\
\text { rush of blood to the head, anorexia, decrease in digestive function, abdominal } \\
\text { chill symptom, abdominalgia due to chill, epigastric discomfort and resistance }\end{array}$ \\
\hline Orengedokuto (OGT) & $\begin{array}{l}\text { multiple stomatitis } \\
\text { irritation, insomnia, rush of blood to the head }\end{array}$ \\
\hline Byakkokaninjinto (BKN) & $\begin{array}{l}\text { thirstiness, dry mouth } \\
\text { hyperidrosis, polyuria }\end{array}$ \\
\hline Shosaikoto (SST) & $\begin{array}{l}\text { bitter in the mouth } \\
\text { irritation, depression, anorexia, hypochondriac discomfort and distension, nausea }\end{array}$ \\
\hline Inchinkoto (ICT) & $\begin{array}{l}\text { multiple stomatitis, dry mouth } \\
\text { irritation, insomnia, constipation, oliguria }\end{array}$ \\
\hline Heiisan (HIS) & $\begin{array}{l}\text { multiple stomatitis } \\
\text { anorexia, decrease in digestive function, abdominal distension }\end{array}$ \\
\hline Juzentaihoto (JTT) & $\begin{array}{l}\text { chronic and repetitive stomatitis, dry mouth } \\
\text { depressed, fatigue, dullness, macies, hot sensation, night sweat, anemia, anorexia, } \\
\text { decrease in digestive function }\end{array}$ \\
\hline Hochuekkito (HET) & $\begin{array}{l}\text { chronic and repetitive stomatitis } \\
\text { depressed, fatigue, dullness, anorexia, decrease in digestive function }\end{array}$ \\
\hline
\end{tabular}

\section{Clinical Studies}

Use of the Kampo formulae has been based on the Kampo medical theories-empirical rules established over thousands of years. In recent years, clinical and basic research studies investigating the Kampo formulae have been performed to obtain scientific evidence.

For our literature review, PubMed (National Center for Biotechnology Information, Bethesda, MD, USA) and ICHUSHI (Japan Medical Abstracts Society, Tokyo, Japan) were used to identify relevant evidence. Reports of clinical studies (randomized controlled trials, case-control studies, and case series studies) identified through this search are summarized in Table 3.

Ogino, et al. [11] showed that the efficacy of SSK administered to patients with cryptogenic stomatitis accompanied by pain $(n=10)$ was $80 \%$. SSK was particularly effective against symptoms such as erosion and redness. Oka [12] investigated the effect of ORT in patients with acute aphthous stomatitis $(n=39)$. The numbers of days until the resolution of pain (2.6 days) and complete cure 
(6.3 days) were reduced in patients treated with ORT compared with those observed in patients treated with a steroid ointment (pain: 7.5 days; cure: 12.3 days).

Currently, there are effective treatment options for chemotherapy- or radiotherapy-induced stomatitis. HST exerts a preventive effect against these types of stomatitis. Yuki, et al. [13] administered OGT for the treatment of chemotherapy-induced stomatitis and diarrhea in patients with acute myeloblastic or lymphoblastic leukemia $(n=40)$. The incidence of stomatitis in ORG-treated patients $(n=14)$ was significantly lower compared with that reported in those who received a gargle consisting of allopurinol, sodium gualenate, and povidone-iodine $(\mathrm{n}=25)(27.9 \% \mathrm{vs.} .71 .6 \%$, respectively; $p<0.0001)$. Moreover, the incidence of diarrhea was significantly lower $(9.3 \%$ vs. $31.7 \%$, respectively; $p<0.005)$. HST has been administered for the treatment of chemotherapy-induced mucositis in patients with various types of cancers, such as colorectal [14-17], gastric [16-18], and renal cancers [19]. In all studies, HST extract granules (TJ-14; Tsumura, Tokyo, Japan) were dissolved in drinking water and subjects rinsed their oral cavity with the solution thrice daily. Kono, et al. [14] reported that $92.8 \%$ of patients (13/14 patients) with chemotherapy-induced oral mucositis (COM) during treatment with mFOLFOX6 or FOLFIRI for metastasis of advanced colorectal cancer showed significant improvement following a 1-week topical application of HST. Moreover, a significantly decreased mean Common Terminology Criteria for Adverse Events grade was reported in patients treated with HST $(p=0.0012)$. Aoyama, et al. [18] conducted a double-blinded, placebo-controlled, randomized study of HST for the treatment of COM in patients with gastric cancer $(n=91)$. Although treatment with HST did not reduce the incidence of grade $\geq 2$ COM, a trend toward the reduction of the risk of grade 1 COM by HST was observed during the screening cycle. Matsuda, et al. [15] also conducted a double-blinded, randomized study investigating the effect of HST against mucositis induced by infusional fluorinated-pyrimidine-based colorectal cancer chemotherapy $(n=93)$. Although the incidence of grade $\geq 2$ mucositis was lower in patients treated with HST than in those treated with placebo, the difference was not statistically significant $(48.8 \%$ vs. $57.4 \%$, respectively; $p=0.41$ ). The median duration of grade $\geq 2$ mucositis was 5.5 days versus 10.5 days, respectively $(p=0.018)$. Nishikawa, et al. [17] demonstrated similar results in patients with gastric and colorectal cancer $(n=181)$, with a median time to improvement from grade $\geq 2$ to grade $<1$ COM of 8 days versus 15 days in the HST and placebo groups, respectively ( $p=0.072$ ). Yoshida, et al. [16] and Ohoka, et al. [19] also administered HST to patients with various types of cancer, demonstrating significant decreases in the Common Terminology Criteria for Adverse Events (v4.0) grades. The findings of these studies suggested that HST may be effective for the treatment of chemotherapy- or radiotherapy-induced stomatitis.

A previous study investigated the administration of JTT for the treatment of radiation-induced stomatitis in patients with oral cancer, in whom oral ingestion was not possible $(n=15)$ [20]. The mean period during which oral ingestion was not possible in these patients showed a reducing trend (i.e., $17.9 \pm 7.1$ days vs. $26.0 \pm 11.6$ days in the JTT-treated $(n=8)$ and non-treated $(n=7)$ groups, respectively $(p<0.121))$. The clinical use of HST for the treatment of radiation-induced stomatitis has also been reported [21,22]. 
Table 3. Clinical studies reporting the use of the Kampo formulae for the treatment of stomatitis.

\begin{tabular}{|c|c|c|c|c|c|}
\hline No. & $\begin{array}{l}\text { First Author, Year } \\
\text { [Reference No.] }\end{array}$ & Kampo Formula & Study Design & Target Patient & Principal Result \\
\hline 1 & Ogino, 1992 [11] & Shosaikoto (SSK) & case series study & cryptogenic stomatitis $(\mathrm{n}=10)$ & $\begin{array}{l}\text { Efficacy rate was } 80 \% . \text { (very effective }=2, \text { effective }=4 \text {, } \\
\text { slightly effective }=2 \text {, no change }=2 \text { ) }\end{array}$ \\
\hline 2 & Oka, 2007 [12] & Orento (ORT) & $\mathrm{RCT}$ & $\begin{array}{l}\text { acute aphthous stomatitis }(n=39)>\text { non-treated }(n=6) \text {, } \\
\text { steroid ointment-treated }(n=6) \text { and ORT-treated }(n=27) \\
\text { groups }\end{array}$ & $\begin{array}{l}\text { The administration of Orento reduced the number of days } \\
\text { until the disappearance of pain and the complete cure } \\
\text { compared to other groups. }\end{array}$ \\
\hline 3 & Yuki, 2003 [13] & $\begin{array}{l}\text { Orengedokuto } \\
\text { (OGT) }\end{array}$ & $\begin{array}{l}\text { case-control } \\
\text { (retrospective) } \\
\text { study }\end{array}$ & $\begin{array}{l}\text { chemotherapy-induced stomatitis in patients with acute } \\
\text { leukemia }(n=40)>\text { ORG-treated }(n=15) \text { and gargling } \\
(n=25) \text { groups }\end{array}$ & $\begin{array}{l}\text { Incidence of stomatitis was } 27.9 \% \text { in the ORG-treated group, } \\
\text { which was significantly lower compared with } 71.6 \% \text { in those } \\
\text { who received a gargle consisting of allopurinol, sodium } \\
\text { gualenate, and povidone-iodine }(p<0.0001) \text {. }\end{array}$ \\
\hline 4 & Kono, 2010 [14] & & case series study & $\begin{array}{l}\text { chemotherapy-induced oral mucositis during mFOLFOX6 } \\
\text { or FOLFIRI treatment for metastasis of advanced colorectal } \\
\text { cancer }(n=14)\end{array}$ & $\begin{array}{l}\text { Thirteen patients }(92.8 \%) \text { showed improvements in oral } \\
\text { mucositis, with significantly decreased mean CTCAE grades } \\
(p=0.0012) \text {. }\end{array}$ \\
\hline 5 & Aoyama, 2014 [18] & & $\mathrm{RCT}$ & $\begin{array}{l}\text { gastric cancer chemotherapy-induced oral mucositis }(\mathrm{COM}) \\
(\mathrm{n}=91)>\text { HST-treated }(\mathrm{n}=45) \text { and placebo }(\mathrm{n}=46) \text { groups }\end{array}$ & $\begin{array}{l}\text { Although HST treatment did not reduce the incidence of } \\
\geq \text { grade } \\
2 \text { COM, a trend was observed in which HST reduced the risk } \\
\text { of COM in the patients who developed grade } 1 \text { COM. }\end{array}$ \\
\hline 6 & Matsuda, 2015 [15] & $\begin{array}{l}\text { Hangeshashinto } \\
\text { (HST) }\end{array}$ & $\mathrm{RCT}$ & $\begin{array}{l}\text { infusional fluorinated-pyrimidine-based colorectal cancer } \\
\text { chemotherapy-induced oral mucositis }(\mathrm{n}=93)> \\
\text { HST-treated }(\mathrm{n}=46) \text { and placebo }(\mathrm{n}=47) \text { groups }\end{array}$ & $\begin{array}{l}\text { Although the incidence of grade } \geq 2 \text { mucositis was lower for } \\
\text { patients treated with HST compared to those treated with } \\
\text { placebo, there was no significant difference ( } 48.8 \text { vs. } 57.4 \% \text {; } \\
p=0.41 \text { ). The median duration of grade } \geq 2 \text { mucositis was } 5.5 \\
\text { versus } 10.5 \text { days ( } p=0.018 \text { ). }\end{array}$ \\
\hline 7 & Yoshida, 2017 [16] & & case series study & $\begin{array}{l}\text { cancer chemotherapy-induced oral mucositis (grade } \geq 2 \text { ) } \\
(\mathrm{n}=50)\end{array}$ & $\begin{array}{l}\text { Thirty-seven patients }(74 \%) \text { showed improvements in oral } \\
\text { mucositis, with significantly decreased mean NRS and } \\
\text { CTC-grade }(p<0.001) \text {. }\end{array}$ \\
\hline 8 & $\begin{array}{l}\text { Nishikawa, } \\
2018[17]\end{array}$ & & $\mathrm{RCT}$ & $\begin{array}{l}\text { chemotherapy-induced oral mucositis }(\mathrm{COM}) \text { in patients } \\
\text { with gastric cancer and colorectal cancer }(\mathrm{n}=181)> \\
\text { HST-treated }(\mathrm{n}=88) \text { and placebo }(\mathrm{n}=93) \text { groups }\end{array}$ & $\begin{array}{l}\text { The incidence of grade } \geq 2 \text { COM in the HST group was } 55.7 \% \text {, } \\
\text { while that in the placebo group was } 53.8 \%(p=0.796) . \\
\text { The median time to remission of grade } \geq 2 \text { COM to grade }<1 \\
\text { was } 8 \text { days in the HST group and } 15 \text { days in the placebo } \\
\text { group }(p=0.072) \text {. }\end{array}$ \\
\hline 9 & Ohoka, 2018 [19] & & $\mathrm{RCT}$ & $\begin{array}{l}\text { sunitinib-induced oral mucositis }(O M) \text { in patients with } \\
\text { metastatic renal cancer }(n=22)>\text { HST-gargling }(n=12) \text { and } \\
\text { non-gargling }(n=10) \text { groups }\end{array}$ & $\begin{array}{l}\text { The gargling with HST significantly improved OM grade and } \\
\text { eating status (Global self assessment) }(p=0.002) \text {. }\end{array}$ \\
\hline 10 & Wada, 2004 [20] & Juzentaihoto (JTT) & $\mathrm{RCT}$ & $\begin{array}{l}\text { radiation }(40 \mathrm{~Gy}>) \text {-induced stomatitis in patients with oral } \\
\text { cancer }(\mathrm{n}=15)>\text { JTT-treated }(\mathrm{n}=8) \text { and non-treated }(\mathrm{n}=7) \\
\text { groups }\end{array}$ & $\begin{array}{l}\text { The mean period that patients could not ingest orally was } \\
17.9 \pm 7.1 \text { days in the JTT-treated group, while that in the } \\
\text { non-treated group was } 26.0 \pm 11.6 \text { day }(p=0.121) .\end{array}$ \\
\hline
\end{tabular}

RCT: randomized controlled trial. 


\section{Basic Studies of HST}

Stomatitis and oral mucositis are induced by various factors, such as infection, inflammation, concomitant oxidative stress, suppressed immunity, depressed function of the digestive tract, malnutrition, psychological stress, and physical stress. Regarding chemotherapy- and radiotherapy-induced mucositis, these treatments induce DNA and non-DNA damage that results in injury of basal epithelial, submucosal, and endothelial cells. In response to this damage, oxidative stress results in the formation of ROS. The presence of ROS damages cell membranes, induces proinflammatory cytokines such as tumor necrosis factor- $\alpha$, prostaglandin (PG) $E_{2}$, interleukin- 6 , and interleukin- $1 \beta$, and upregulates cyclooxygenase (COX)-2 in submucosal fibroblasts and endothelial cells leading to mucosal ulceration $[23,24]$. Furthermore, chemotherapy and radiotherapy reduce immunity, facilitating the development of infectious diseases [25].

Hitomi, et al. [26] conducted in-vivo studies evaluating the analgesic effects of HST using an oral ulcer rat model treated with acetic acid. The topical application of HST in ulcerative oral mucosa suppressed mechanical pain hypersensitivity without exerting effects on healthy mucosa. Moreover, Kamide, et al. [27] assessed the effectiveness of HST for the prevention of radiation-induced mucositis using a hamster model. Administration of HST significantly reduced the severity of mucositis. The percentage of severe mucositis (score $\geq 3$ ) was $100 \%$ and $16.7 \%$ in the untreated and HST groups, respectively. Moreover, HST inhibited the infiltration of neutrophils and expression of COX-2 in irradiated mucosa.

As mentioned earlier in this review, the main characteristic of the Kampo formulae is the combination of several crude drugs (Table 1). These combinations may suppress multiple causes of stomatitis and mucositis. Of note, HST is composed of seven herbs, namely Scutellariae Radix, Glycyrrhizae Radix, Zizyphi Fructus, Ginseng Radix, Pinelliae Tuber, Zingiberis Rhizoma Processum, and Coptidis Rhizoma. These constituents, except Pinelliae Tuber, exert antioxidative effects [7,28]. Matsumoto, et al. [28] reported that Glycyrrhizae Radix, Ginseng Radix, and Zizyphi Fructus demonstrated scavenging activity for hydroxyl radical, while Scutellariae Radix, Glycyrrhizae Radix, Zingiberis Rhizoma Processum, and Coptidis Rhizoma eliminated superoxide. Moreover, Scutellariae Radix and Coptidis Rhizoma have been shown to eliminate nitroxyl radical.

Regarding its antibacterial action, in vitro studies demonstrated that HST extract inhibited the growth of Gram-negative bacteria including Fusobacterium nucleatum, Porphyromonas gingivalis, Porphyromonas endodontalis, Prevotella intermedia, Prevotella melaninogenica, Tannerella forsythia, Treponema denticola, and Porphyromonas asaccharolytica. However, these inhibitory effects were less pronounced in Gram-positive bacteria and Candida albicans. These effects are thought to be induced by Scutellariae Radix (baicalein), Pinelliae Tuber (homogentisic acid), Zingiberis Rhizoma Processum ([6]-shogaol) and Coptidis Rhizoma (berberine, coptisine) [29]. Furthermore, Glycyrrhizae Radix [30,31], Pinelliae Tuber [31], Coptidis Rhizoma [32], and Ginseng Radix may enhance immunity. In particular, Ginseng Radix was reported to increase the activity of natural killer cells in mice treated orally with it $[33,34]$.

Regarding its anti-inflammatory effect, $\mathrm{HST}$ inhibited the production of $\mathrm{PGE}_{2}$ and suppressed the expression of COX-2 protein. In vitro studies show that Scutellariae Radix, Glycyrrhizae Radix, Zingiberis Rhizoma Processum, and Coptidis Rhizoma are involved in these effects [35-38]. As stated earlier in this review, Hitomi, et al. reported the analgesic action of HST [26] and subsequently found through in vitro and in vivo studies that blockage of $\mathrm{Na}^{+}$channels by components of Zingiberis Rhizoma Processum ([6]-gingerol and ([6]-shogaol) play an essential role in HST-associated analgesia. Moreover, the Ginseng Radix extract demonstrated an acceleration of substance permeability into the tissue of the oral ulcer and enhanced the analgesic action of Zingiberis Rhizoma Processum [39]. Baicalein-an active constituent of Scutellariae Radix-alleviated mechanical allodynia in rats with cancer-induced bone pain [40]. Glycyrrhizin—an active constituent of Glycyrrhizae Radix—ameliorated inflammatory pain by inhibiting the microglial activation-mediated inflammatory response in mice with inflammatory pain [41]. HST induces its analgesic effect through the synergistic actions of certain crude drugs. 
Therefore, HST exerts a combination of antioxidative, anti-inflammatory, immunostimulatory, and analgesic effects. Moreover, HST is able to control the symptoms and simultaneously eliminate the underlying causes of the condition (Figure 2).

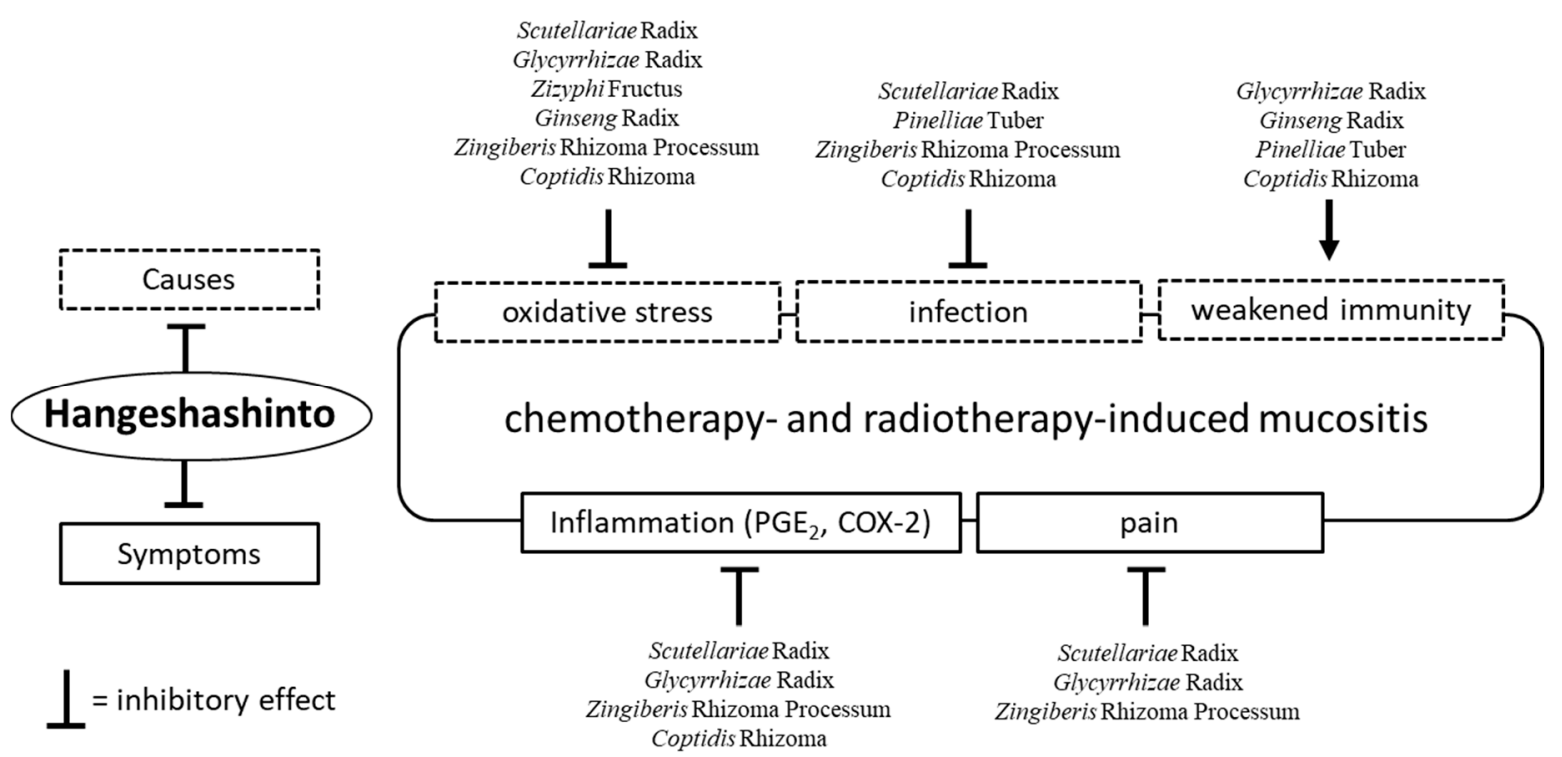

Figure 2. The effects of Hangeshashinto (HST) and the crude drugs on chemotherapy- and radiotherapy-induced mucositis. HST exerts antioxidative, anti-inflammatory, immunostimulatory, and analgesic effects. Moreover, HST is able to control the symptoms and simultaneously eliminate the underlying causes of the condition. $\mathrm{PGE}_{2}$; prostaglandin $\mathrm{E}_{2}$. COX-2; cyclooxygenase-2.

\section{Conclusions}

In general, western medicines such as steroid ointments, nonsteroidal anti-inflammatory drugs, and antiviral and antifungal drugs are applied for stomatitis and oral mucositis according to the causes and symptoms. In contrast to western medicines which generally include a single component, the Kampo formulae contain multiple components and their effects are exerted through complex mechanisms of action. Use of the Kampo formulae may be an alternative treatment option for patients who failed to respond to conventional therapies. In addition, the concomitant use of Kampo formulae with western medicines may be useful. Kobayashi [42] reported effective cases in which the concomitant use of HST with steroid ointment was applied. In this review, we introduced the clinical applications and summarized the available evidence of the Kampo formulae for the treatment of stomatitis and oral mucositis. Despite the availability of clinical reports, the evidence (except for that related to treatment with HST) is limited. Future clinical and basic research studies are warranted to further investigate the effectiveness on the Kampo formulae against these conditions.

Author Contributions: T.H. designed and supervised the work. M.S. wrote the initial draft with support from M.T., N.E. and H.I., and K.Y. edited the manuscript. All authors approved the final version of the manuscript.

Funding: This research received no external funding.

Acknowledgments: The authors would like to thank Shigemasa Kubo for his valuable assistance during the preparation of this manuscript and Enago (www.enago.jp) for English language review.

Conflicts of Interest: The authors declare no conflict of interest.

\section{Abbreviations}

BKN Byakkokaninjinto

COM chemotherapy-induced oral mucositis

COX cyclooxygenase

HET Hochuekkito 


$\begin{array}{ll}\text { HST } & \text { Hangeshashinto } \\ \text { ICT } & \text { Inchinkoto } \\ \text { IL } & \text { interleukin } \\ \text { JTT } & \text { Juzentaihoto } \\ \text { OGT } & \text { Orengedokuto } \\ \text { ORT } & \text { Orento } \\ \text { PG } & \text { prostaglandin } \\ \text { RCT } & \text { randomized controlled trial } \\ \text { ROS } & \text { reactive oxygen species } \\ \text { SST } & \text { Shosaikoto }\end{array}$

\section{References}

1. Curra, M.; Junior, S.; Valente, L.A.; Martins, M.D.; Santos, P.S.D.S. Chemotherapy protocols and incidence of oral mucositis. An integrative review. Einstein 2018, 16, eRW4007. [CrossRef] [PubMed]

2. Zheng, L.W.; Hua, H.; Cheung, L.K. Traditional Chinese medicine and oral diseases: Today and tomorrow. Oral Dis. 2011, 17, 7-12. [CrossRef] [PubMed]

3. Yamaguchi, K. Traditional Japanese herbal medicines for treatment of odontopathy. Front. Pharmacol. 2015, 6, 176. [CrossRef] [PubMed]

4. Sunagawa, M.; Wang, P.L.; Yohkoh, N.; Kameyama, A.; Mukunashi, K.; Mori, S.; Makiishi, T.; Takahashi, S. Survey on trends in the use of Kampo medicines in dentistry and oral surgery among the hospitals of universities. J. Jpn. Dent. Soc. Orient. Med. 2011, 30, 8-17. (In Japanese)

5. Kenkyukai, K.C. Clinical Research of Chinese Traditional Medicine-Pharmacognosy, 1st ed.; Ishiyaku Publishers, Inc.: Tokyo, Japan, 1992; pp. 36-553. ISBN 4-263-73065-8. (In Japanese)

6. Tugrul, S.; Koçyiğit, A.; Doğan, R.; Eren, S.B.; Senturk, E.; Ozturan, O.; Ozar, O.F. Total antioxidant status and oxidative stress in recurrent aphthous stomatitis. Int. J. Dermatol. 2016, 55, e130-e135. [CrossRef] [PubMed]

7. Dragland, S.; Senoo, H.; Wake, K.; Holte, K.; Blomhoff, R. Several culinary and medicinal herbs are important sources of dietary antioxidants. J. Nutr. 2003, 133, 1286-1290. [CrossRef] [PubMed]

8. Toriizuka, K. Monographs of Pharmacological Research on Traditional Herbal Medicine; Ishiyaku Publishers, Inc.: Tokyo, Japan, 2003; pp. 9-379. ISBN 978-4-263-20188-6. (In Japanese)

9. Ikemoto, T.; Shimada, M.; Iwahashi, S.; Saito, Y.; Kanamoto, M.; Mori, H.; Morine, Y.; Imura, S.; Utsunomiya, T. Changes of immunological parameters with administration of Japanese Kampo medicine (Juzen-Taihoto/TJ-48) in patients with advanced pancreatic cancer. Int. J. Clin. Oncol. 2014, 19, 81-86. [CrossRef]

10. Kuroiwa, A.; Liou, S.; Yan, H.; Eshita, A.; Naitoh, S.; Nagayama, A. Effect of a traditional Japanese herbal medicine, hochu-ekki-to (Bu-Zhong-Yi-Qi Tang), on immunity in elderly persons. Int. Immunopharmacol. 2004, 4, 317-324. [CrossRef]

11. Ogino, S.; Harada, T. The effects of Tsumura Shosaikoto on stomatitis. J. New Rem. Clin. 1992, 41, 592-595. (In Japanese)

12. Oka, S. The effects of Oren-to on Stomatitis. Pharm. Med. 2007, 25, 35-38. (In Japanese)

13. Yuki, F.; Kawaguchi, T.; Hazemoto, K.; Asou, N. Preventive effects of oren-gedoku-to on mucositis caused by anticancer agents in patients with acute leukemia. Jpn. Cancer Chemother. 2003, 30, 1303-1307. (In Japanese)

14. Kono, T.; Satomi, M.; Chisato, N.; Ebisawa, Y.; Suno, M.; Asama, T.; Karasaki, H.; Matsubara, K.; Furukawa, H. Topical Application of Hangeshashinto (TJ-14) in the Treatment of Chemotherapy-Induced Oral Mucositis. World J. Oncol. 2010, 1, 232-235. [PubMed]

15. Matsuda, C.; Munemoto, Y.; Mishima, H.; Nagata, N.; Oshiro, M.; Kataoka, M.; Sakamoto, J.; Aoyama, T.; Morita, S.; Kono, T. Double-blind, placebo-controlled, randomized phase II study of TJ-14 (Hangeshashinto) for infusional fluorinated-pyrimidine-based colorectal cancer chemotherapy-induced oral mucositis. Cancer Chemother. Pharmacol. 2015, 76, 97-103. [CrossRef] [PubMed]

16. Yoshida, N.; Taguchi, T.; Okayama, T.; Ishikawa, T.; Naito, Y.; Kanazawa, M.; Kanbayashi, Y.; Hosokawa, T.; Kohno, R.; Ito, Y. The effects of Hangeshashinto infiltration method for cancer chemotherapy-induced oral mucositis. Prog. Med. 2017, 37, 1339-1343. (In Japanese) 
17. Nishikawa, K.; Aoyama, T.; Oba, M.S.; Yoshikawa, T.; Matsuda, C.; Munemoto, Y.; Takiguchi, N.; Tanabe, K.; Nagata, N.; Imano, M.; et al. The clinical impact of Hangeshashinto (TJ-14) in the treatment of chemotherapy-induced oral mucositis in gastric cancer and colorectal cancer: Analyses of pooled data from two phase II randomized clinical trials (HANGESHA-G and HANGESHA-C). J. Cancer 2018, 9, 1725-1730. [CrossRef]

18. Aoyama, T.; Nishikawa, K.; Takiguchi, N.; Tanabe, K.; Imano, M.; Fukushima, R.; Sakamoto, J.; Oba, M.S.; Morita, S.; Kono, T.; et al. Double-blind, placebo-controlled, randomized phase II study of TJ-14 (hangeshashinto) for gastric cancer chemotherapy-induced oral mucositis. Cancer Chemother. Pharmacol. 2014, 73, 1047-1054. [CrossRef] [PubMed]

19. Ohoka, H. The Clinical Usefulness of Gargling with Hangeshashinto for Treatment of Oral Mucositis Caused by Sunitinib in Patients with Metastatic Renal Cancer. Kampo Med. 2018, 69, 1-6. (In Japanese) [CrossRef]

20. Wada, S.; Furuta, I. The preventive effects of Juzentaihoto on side effects of radiation therapy for oral cancer. Sci. Kampo Med. 2004, 28, 76-78. (In Japanese)

21. Nagai, A.; Ogawa, K.; Miura, J.; Kobayashi, K. Therapeutic effects of Hangeshashinto, a Japanese Kampo medicine, on radiation-induced enteritis and oral mucositis: Case series. Kampo Med. 2014, 65, 108-114. (In Japanese) [CrossRef]

22. Tanaka, Y.; Yamashita, T.; Matsunobu, T.; Shiotani, A. Two Cases of Radiotherapy-induced Oral Mucositis Alleviated with Hange-shashin-to. Pract. Oto-Rhino-Laryngol. 2012, 105, 1199-1203. (In Japanese) [CrossRef]

23. Logan, R.M.; Gibson, R.J.; Sonis, S.T.; Keefe, D.M. Nuclear factor-kappaB (NF-kappaB) and cyclooxygenase-2 (COX-2) expression in the oral mucosa following cancer chemotherapy. Oral Oncol. 2007, 43, 395-401. [CrossRef] [PubMed]

24. Al-Dasooqi, N.; Gibson, R.J.; Bowen, J.M.; Logan, R.M.; Stringer, A.M.; Keefe, D.M. Matrix metalloproteinases are possible mediators for the development of alimentary tract mucositis in the dark agouti rat. Exp. Biol. Med. 2010, 235, 1244-1256. [CrossRef] [PubMed]

25. Al-Ansari, S.; Zecha, J.A.; Barasch, A.; de Lange, J.; Rozema, F.R.; Raber-Durlacher, J.E. Oral Mucositis Induced by Anticancer Therapies. Curr. Oral Health Rep. 2015, 2, 202-211. [CrossRef] [PubMed]

26. Hitomi, S.; Ono, K.; Yamaguchi, K.; Terawaki, K.; Imai, R.; Kubota, K.; Omiya, Y.; Hattori, T.; Kase, Y.; Inenaga, $\mathrm{K}$. The traditional Japanese medicine hangeshashinto alleviates oral ulcer-induced pain in a rat model. Arch. Oral Biol. 2016, 66, 30-37. [CrossRef] [PubMed]

27. Kamide, D.; Yamashita, T.; Araki, K.; Tomifuji, M.; Shiotani, A. Hangeshashinto (TJ-14) prevents radiation-induced mucositis by suppressing cyclooxygenase-2 expression and chemotaxis of inflammatory cells. Clin. Transl. Oncol. 2017, 19, 1329-1336. [CrossRef]

28. Matsumoto, C.; Sekine-Suzuki, E.; Nyui, M.; Ueno, M.; Nakanishi, I.; Omiya, Y.; Fukutake, M.; Kase, Y.; Matsumoto, K. Analysis of the antioxidative function of the radioprotective Japanese traditional (Kampo) medicine, hangeshashinto, in an aqueous phase. J. Radiat. Res. 2015, 56, 669-677. [CrossRef]

29. Fukamachi, H.; Matsumoto, C.; Omiya, Y.; Arimoto, T.; Morisaki, H.; Kataoka, H.; Kadena, M.; Funatsu, T.; Fukutake, M.; Kase, Y.; et al. Effects of Hangeshashinto on Growth of Oral Microorganisms. Evid. Based Complement. Alternat. Med. 2015, 2015, 512947. [CrossRef]

30. Chan, A.; Pang, H.; Yip, E.C.; Tam, Y.K.; Wong, Y.H. The aqueous extract of Radix Glycyrrhizae stimulates mitogen-activated protein kinases and nuclear factor-kappaB in Jurkat T-cells and THP-1 monocytic cells. Am. J. Chin. Med. 2006, 34, 263-278. [CrossRef]

31. Matsuura, K.; Kawakita, T.; Nakai, S.; Saito, Y.; Suzuki, A.; Nomoto, K. Role of B-lymphocytes in the immunopharmacological effects of a traditional Chinese medicine, xiao-chai-hu-tang (shosaiko-to). Int. J. Immunopharmacol. 1993, 15, 237-243. [CrossRef]

32. Zhou, X.; Peng, Y.; Li, L.; He, K.; Huang, T.; Mou, S.; Feng, M.; Han, B.; Ye, X.; Li, X. Effects of dietary supplementations with the fibrous root of Rhizoma Coptidis and its main alkaloids on non-specific immunity and disease resistance of common carp. Vet. Immunol. Immunopathol. 2016, 173, 34-38. [CrossRef]

33. Jang, A.Y.; Song, E.J.; Shin, S.H.; Hwang, P.H.; Kim, S.Y.; Jin, Y.W.; Lee, E.K.; Lim, M.J.; Oh, I.S.; Ahn, J.Y.; et al. Potentiation of natural killer (NK) cell activity by methanol extract of cultured cambial meristematic cells of wild ginseng and its mechanism. Life Sci. 2015, 135, 138-146. [CrossRef] [PubMed]

34. Liou, C.J.; Huang, W.C.; Tseng, J. Short-term oral administration of ginseng extract induces type-1 cytokine production. Immunopharmacol. Immunotoxicol. 2006, 28, 227-240. [CrossRef] [PubMed] 
35. Kato, T.; Segami, N.; Sakagami, H. Anti-inflammatory Activity of Hangeshashinto in IL-1 $\beta$-stimulated Gingival and Periodontal Ligament Fibroblasts. In Vivo 2016, 30, 257-263. [PubMed]

36. Kaneko, T.; Chiba, H.; Horie, N.; Kato, T.; Kobayashi, M.; Hashimoto, K.; Kusama, K.; Sakagami, H. Effect of Scutellariae radix ingredients on prostaglandin E(2) production and COX-2 expression by LPS-activated macrophage. In Vivo 2009, 23, 577-581. [PubMed]

37. Kase, Y.; Saitoh, K.; Ishige, A.; Komatsu, Y. Mechanisms by which Hange-shashin-to reduces prostaglandin E2 levels. Biol. Pharm. Bull. 1998, 21, 1277-1281. [CrossRef] [PubMed]

38. Kono, T.; Kaneko, A.; Matsumoto, C.; Miyagi, C.; Ohbuchi, K.; Mizuhara, Y.; Miyano, K.; Uezono, Y. Multitargeted effects of hangeshashinto for treatment of chemotherapy-induced oral mucositis on inducible prostaglandin E2 production in human oral keratinocytes. Integr. Cancer Ther. 2014, 13, 435-445. [CrossRef] [PubMed]

39. Hitomi, S.; Ono, K.; Terawaki, K.; Matsumoto, C.; Mizuno, K.; Yamaguchi, K.; Imai, R.; Omiya, Y.; Hattori, T.; Kase, Y.; et al. [6]-gingerol and [6]-shogaol, active ingredients of the traditional Japanese medicine hangeshashinto, relief oral ulcerative mucositis-induced pain via action on $\mathrm{Na}^{+}$channels. Pharmacol. Res. 2017, 117, 288-302. [CrossRef] [PubMed]

40. Hu, S.; Chen, Y.; Wang, Z.F.; Mao-Ying, Q.L.; Mi, W.L.; Jiang, J.W.; Wu, G.C.; Wang, Y.Q. The Analgesic and Antineuroinflammatory Effect of Baicalein in Cancer-Induced Bone Pain. Evid. Based Complement. Altern. Med. 2015, 2015, 973524. [CrossRef]

41. Sun, X.; Zeng, H.; Wang, Q.; Yu, Q.; Wu, J.; Feng, Y.; Deng, P.; Zhang, H. Glycyrrhizin ameliorates inflammatory pain by inhibiting microglial activation-mediated inflammatory response via blockage of the HMGB1-TLR4-NF-kB pathway. Exp. Cell Res. 2018, 369, 112-119. [CrossRef]

42. Kobayashi, E. Clinical study on 184 cases of stomatitis. J. Kampo Med. 2007, 54, 108-115. (In Japanese)

(C) 2018 by the authors. Licensee MDPI, Basel, Switzerland. This article is an open access article distributed under the terms and conditions of the Creative Commons Attribution (CC BY) license (http:/ / creativecommons.org/licenses/by/4.0/). 